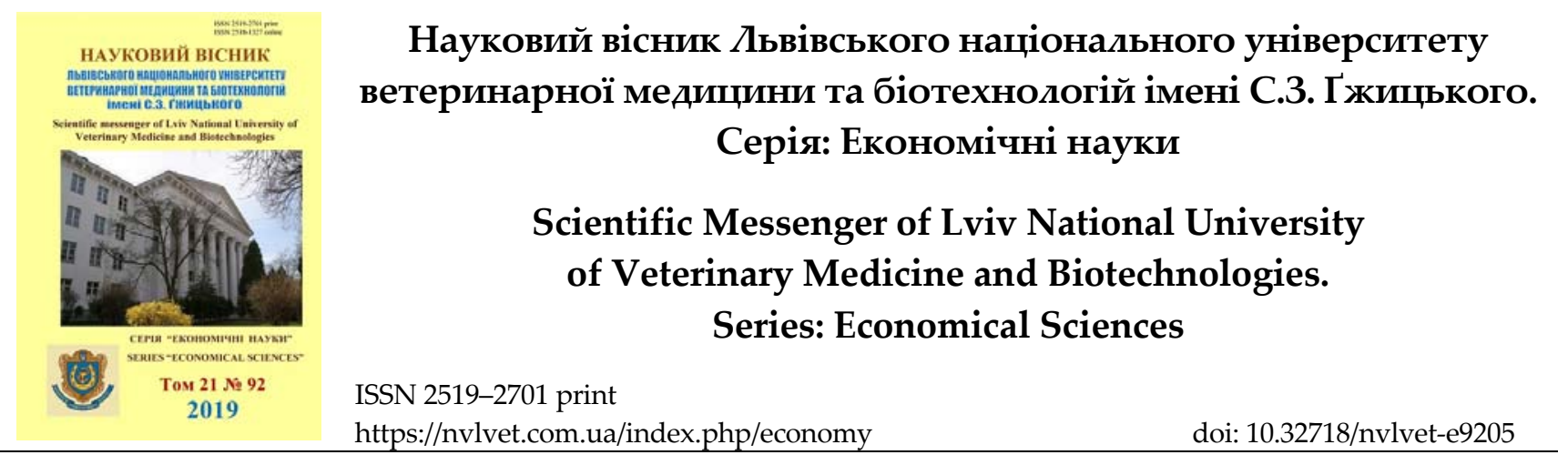

UDC 338.432(477.83)

\title{
The state of production and marketing of agrarian products by agricultural enterprises of Lviv region
}

\author{
R. Komaniak
}

Stepan Gzhytskyi National University of Veterinary Medicine and Biotechnologies Lviv, Ukraine

Article info

Received 17.01.2019

Received in revised form 21.02.2019

Accepted 22.02.2019

Stepan Gzhytskyi National University of Veterinary Medicine and Biotechnologies Lviv, Pekarska Str., 50, Lviv, 79010, Ukraine.

Tel.: +38-067-859-54-58 E-mail: komanyak.ruslan1994@gmail.com
Komaniak, R. (2019). The state of production and marketing of agrarian products by agricultural enterprises of Lviv region. Scientific Messenger of Lviv National University of Veterinary Medicine and Biotechnologies. Series: Economical Sciences, 21(92), 27-32. doi: 10.32718/nvlvet-e9205

In this publication the research of activity of one of the important components of the subjects of agrarian, namely: functioning of agricultural enterprises, was conducted. These organizational and economic structures in the agrarian sector of the economy have fallen in the early stages of the implementation of agrarian reforms in Ukraine (at the end of the 20th century). This is the result of unwarranted transformations in agriculture. In modern conditions, and they began in the early 21st century, there are dynamic processes of the revival of large-scale agricultural production, based on which agricultural enterprises. It is these organizational and economic structures of the Lviv region that underlies the preparation and writing of this article. The presentation of the research results was conducted in a certain logical publication. The introduction substantiates the relevance of the chosen topic of studying its significance for the further development of agrarian production, it is indicated in the selection of research activities of agricultural enterprises of Lviv region during 2000-2017. The specific effects of the research are reflected in the numerical indicators in tabular forms. Thus, in particular, shows the volumes of production for the above-mentioned years and its share in its total volumes in the Lviv region. The above information gives grounds to assert that the agricultural enterprises of Lviv region dynamically increase the absolute indicators of gross production of agrarian products in general and in sectoral terms in particular. The publication presents data on the level of use of agricultural land by investigated subjects of economic activity. There are also positive changes and indicators of production of agrarian products per 100 hectares of agricultural land are much higher than in the farms of the population, which in the Lviv region is the dominant form of management. The volumes of sales of agricultural products by agricultural enterprises are presented in the natural indices for its main types, which also have a strong tendency to increase, with the exception of some types of livestock products. The publication also presents the dynamics of changes in prices for the represented types of crop and livestock products, and at the same time we note that in order to establish certain patterns of their changes, it is necessary to carry out separate studies on the functioning of the price mechanism in the agrarian sector of the economy. Conclusions are derived from the results of the study and are specific. Their implementation should ensure the growth of production and implementation of agricultural products by agricultural enterprises of Lviv region in such quantities that would ensure the domination of these organizational and economic structures in the agrarian sector of the economy.

Key words: agricultural enterprises, economy of the population, production, production, sale, plant growing, animal husbandry, agricultural lands, prices.

\section{Стан виробництва і реалізації аграрної продукції сільськогосподарськими підприсмствами Львівщини}

\section{Р.3. Команяк}

Львівський національний університет ветеринарної медицини та біотехнологій імені С.3. Гжицького, м. Львів, Украӥна 
В даній публікації проведено дослідження діяльності однієї із важливих складових суб'єктів аграрного виробництва, а саме: функціонування сільськогосподарських підприємств. Ці організаційно-господарські структури в аграрному секторі економіки занепали на початкових періодах здійснення аграрних реформ в Украӥні (в кінці 20 ст). В сучасних умовах, а вони почалися на початку 21 cm., відбуваються динамічні прочеси відродження крупного аграрного виробництва, основою яких є сільськогосподарські підприємства. Саме иі організаційно-господарські структури Львівської області покладено в основу підготовки і написання даної статті. У вступі обтрунтовано актуальність обраної теми дослідження, ї̈ значущість для подальшого розвитку аграрного виробництва. Конкретні наслідки досліджень відображені в циифрових показниках у табличних формах. Так, зокрема показано обсяги виробництва продукції за вищевказані роки та ї̈ питома вага в загальних ї̈ обсягах у Львівській області. Наведена інформація дає підстави стверджувати, що сільськогосподарські підприємства Львівщини динамічно нарощують абсолюті показники валового виробництва аграрної продукції загалом і в галузевому розрізі зокрема. В публікації наведені дані щзодо рівня використання сільськогосподарських угідь досліджуваними суб' єктами господарювання. Також спостерігаються позитивні зміни і показники виробництва аграрної продукції з розрахунку на 100 га сільськогосподарських угідь, є значно вищі, ніж у господарствах населення, які на Львівщчні є домінуючою формою господарювання. Обсяги реалізації продукиї сільського господарства сільськогосподарськими підприємствами подані в натуральних показниках за основними ї̈ видами, які також мають тенденцію до зростання за винятком деяких видів тваринницької продукиії. В публікації також показано динаміку змін иүін на продукцію рослинництва і тваринництва, i одночасно зауважимо, щуо для встановлення певних закономірностей їх змін необхідно проводити окремі дослідження щзодо функціонування изінового механізму в аграрному секторі економіки. Висновки випливають із результатів дослідження і мають конкретний характер. Їх реалізація повинна забезпечити зростання виробництва і продажу аграрної продукції сільськогосподарськими підприємствами Львівщини в таких обсягах, які б забезпечили б домінування цих організаційно-господарських структур в аграрному секторі економіки.

Ключові слова: сільськогосподарські підприємства, господарства населення, виробництво, продукція, реалізація, рослинництво, тваринництво, сільськогосподарські угіддя, ичіни.

\section{Вступ}

Розвиток аграрного виробництва в сучасних умовах характеризується функціонуванням різноманітних організаційно-правових форм господарювання, важливе місце серед яких займають сільськогосподарські підприємства. Ці господарські формування характеризуються цілим комплексом відмінних ознак у процесах здійснення виробничої діяльності, одна з основних яких полягає у широкомасштабності виробництва і реалізації виробленої аграрної продукції. Одночасно зауважимо, що ці організаційно-господарські структури завдяки наявності у них значних земельних, трудових, матеріально-технічних та інших ресурсів мають широкі можливості для впровадження передових технологій виробництва продукції, використання прогресивних форм організації праці, іiї оплати та інше. Все це в комплексі дає підстави стверджувати, що ці суб'єкти господарювання повинні стати важливим і пріоритетним напрямом у розвитку аграрної економіки як у сучасних умовах, так і на перспективу.

Все, що вище викладено, обумовило вибір теми дослідження. Безумовно, розглянути багатогранну i різноманітну діяльність сільськогосподарських підприємств в одній публікації практично неможливо. Саме через ці обставини нами обрано одну із важливих складових їхньої діяльності, а саме: виробництво аграрної продукції та іiі реалізацію. Для прикладу використано матеріал щодо функціонування сільськогосподарських підприємств Львівщини протягом 2000-2017 pp.

\section{Матеріал і методи досліджень}

В процесі проведення досліджень діяльності сільськогосподарських підприємств використано матеріал, що відображено у працях багатьох як вчених аграрників, так і практиків. Це зокрема такі вчені як В.Г. Андрійчук, В.Я. Месель-Веселяк, М.Г. Шульський, Я.М. Гадзало, В.М. Жук, Ю.О. Лупенко та інші
(Andriichuk, 2005; Mesel-Veseliak, 2012; Hadzalo et al., 2016; Shulskyj, 2016; Smolynec, 2017). Хоча в науковій літературі всебічно проведено висвітлення функціонування сільськогосподарських підприємств як минулих, так і сучасних періодів їх розвитку, однак деякі аспекти їх діяльності вимагають постійного дослідження з врахуванням фактору часу. Сутність цього твердження обумовлено тим, що кожен господарський рік вносить різні зміни в діяльність сільськогосподарських підприємств, які, безумовно, характеризуються певними показниками їх розвитку, серед яких виділяються виробництво i реалізація виробленої ними аграрної продукції. Інформація, що відтворює зміни цих показників за певні періоди, подається найбільш повно в джерелах статистичних джерелах. Даний матеріал, що міститься в статистичних виданнях, використано нами при підготовці публікації.

Зібрані матеріали оброблялися 3 використанням методів економічних досліджень. Теоретичною основою даної публікації є діалектичний метод пізнання. В процесах проведення досліджень використовувались такі методи: економіко-статистичні, розрахунково-конструктивний, системний аналіз, монографічний та інші. Обробка зібраного матеріалу, що проведена 3 використанням різноманітних методів економічних досліджень, дозволила виконати сформовані завдання і таким чином досягти поставленої мети.

\section{Результати та їх обговорення}

Виробництво і реалізація аграрної продукції здійснюється різними організаційно-господарськими формуваннями, важливе місце серед яких займають сільськогосподарські підприємства. В економічностатистичній літературі їх трактують, як “суб”єкт господарювання, який має статус юридичної особи, або відокремлений підрозділ юридичної особи, що здійснює систематичну виробничу діяльність у галузі сільського господарства. До складу сільськогосподарських підприємств відносять також фермерські господарства" (Korysko, 2018). У загальному таке визна- 
чення відповідає суті діяльності цих підприємств, однак $з$ деяким уточненням. Ми вважаємо, що кожна форма господарювання повинна займати свою окрему нішу у сферах аграрного виробництва, а не відображати свою діяльність в загальних показниках розвитку тієї чи іншої форми господарювання. Тим паче, що фермерські господарства як суб'єкт господарювання здійснюють свою діяльність відповідно до діючих статутів, в яких враховується особливість іiі функціонування. До того ж статистичні видання виділяють окремо результати діяльності фермерських господарств не завжди сумарно із сільськогосподарськими підприємствами.

Результати діяльності як сільськогосподарських підприємств, так і інших організаційно-господарських структур у системі АПК характеризуються цілим компексом різноманітних показників. I це цілком об'єктивно й закономірно, адже аграрне виробництво $\epsilon$ однією із найскладніших галузей національного господарства, де значний вплив мають природні фактори, на які не можливо пвлинути. Якими би складними не були умови господарювання суб'єктів діяльності в тій чи тій галузі, однак об'єднуючими показниками їх функціонування є виробництво і реалізація продукції. Саме за цими показниками проводиться дослідження діяльності будь-яких господарських структур національного господарства держави. Враховуючи ці аспекти, нами і обрано тему дослідження 3 діяльності однієї із важливих форм господарювання в аграрному секторі економіки - сільськогосподарських підприємств на прикладі їх розвитку у Львівській області. Насамперед наведемо обсяги виробництва аграрної продукції сільськогосподарськими підприємствами Львівщини протягом 2000-2017 рр. (табл. 1).

\section{Таблиця 1*}

Обсяги виробництва аграрної продукції сільськогосподарськими підприємствами Львівщини за 2000-2017 рр., у постійних цінах 2010 року

\begin{tabular}{|c|c|c|c|c|c|c|c|}
\hline \multirow[b]{2}{*}{ Продукція } & \multirow[t]{2}{*}{2000} & \multirow[t]{2}{*}{2005} & \multirow[t]{2}{*}{2010} & \multirow[t]{2}{*}{2015} & \multirow[t]{2}{*}{2017} & \multicolumn{2}{|c|}{2017 у \% до } \\
\hline & & & & & & 2000 & 2015 \\
\hline \multirow{2}{*}{ Усього } & $679,8 * *$ & 738,8 & 1862,2 & 3045,0 & 3816,9 & 5,6 раза & 125,3 \\
\hline & $9,8 * * *$ & 10,4 & 25,3 & 33,7 & 38,9 & $+29,1$ & $+5,2$ \\
\hline \multirow{2}{*}{$\begin{array}{l}\text { у тому числі продукція: } \\
\text { рослинництва }\end{array}$} & 522,7 & 493,6 & 1034,1 & 2065,9 & 2651,1 & 5,1 раза & 128,3 \\
\hline & 7,5 & 6,9 & 14,1 & 22,9 & 27,0 & $+19,5$ & $+4,1$ \\
\hline \multirow{2}{*}{ тваринництва } & 157,1 & 245,2 & 828,1 & 979,1 & 1165,8 & 7,4 раза & 119,1 \\
\hline & 2,3 & 3,5 & 11,2 & 10,8 & 11,9 & $+9,6$ & $+1,1$ \\
\hline
\end{tabular}

Примітка: * тут і надалі використано матеріали статистичного щорічника (Zymovina, 2018).

** чисельник - вартість виробленої продукції, млн грн.;

*** знаменник - питома вага виробленої продукції в загальних обсягах її виробництва всіма господарствами області, \%

Наведені дані показують, що виробництво аграрної продукції сільськогосподарськими підприємствами Львівської області характеризується позитивними тенденціями зростання. Так, скажімо, вартість усієї виробленої продукції зросла у 2017 р. до 3816,9 млн грн., що більше порівняно з 2000 р. у понад 5 разів. Відповідні зміни відбулися щодо питомої ваги виробленої продукції цими господарствами у загальних обсягах iï виробництва в області. Аналогічні зміни спостерігаються і в розрізі окремих галузей - рослинництва і тваринництва.

Отже, результати проведеного аналізу дають підстави стверджувати, що у виробництві аграрної продукції сільськогосподарськими підприємствами Львівщини протягом 2000-2017 рр. відбулись позитивні зміни - збільшилися їх обсяги виробництва, з одного боку, та підвищення їх питомої ваги у загальній структурі її виробництва загалом в області, з іншого. Проте ці зміни не забезпечили їх домінування в аграрному виробництві Львівщини. Валове виробництво аграрної продукції суб'єктами господарювання в значній мірі залежить від рівня використання ними земельних угідь в процесах іiі продукування. Для цього в економічній практиці використовується такий показник, як вихід продукції на 100 га сільськогосподарських угідь, величини якого для сільськогосподарських підприємств Львівщини наведено в таблиці 2 .

Аналіз наведених даних дає підстави стверджувати таке:

- сільськогосподарські підприємства протягом досліджуваного періоду постійно і динамічно нарощували виробництво аграрної продукції в розрахунку на 100 га сільськогосподарських угідь із 98,3 тис. грн у 2000 р. до 1281,2 тис. грн у 2017 р., тобто зростання становить 13 разів. Аналогічні тенденції спостерігаються в розрізі окремих галузей: рослинництва і тваринництва. При цьому темпи зростання виробництва тваринницької продукції перевищують темпи зростання рослинницької, однак, з іншого боку, виробництво продукції тваринництва $є$ майже у два рази меншим, ніж рослинницької;

- щодо господарств населення. Тут ситуація протилежна, показники виробництва продукції сільського господарства цими агроформуваннями 3 розрахунку на 100 га сільськогосподарських угідь як у загальних обсягах, так так і в галузевому розрізі зменшились. 


\section{Таблиця 2}

Продукція сільського господарства з розрахунку на 100 га сільськогосподарських угідь окремих форм господарювання Львівщини за 2000-2017 рр., в постійних цінах 2010 р. тис. грн.

\begin{tabular}{|c|c|c|c|c|c|c|c|}
\hline \multirow{2}{*}{$\begin{array}{l}\text { Продукція } \\
\text { Роки }\end{array}$} & \multirow{2}{*}{2000} & \multirow{2}{*}{2005} & \multirow{2}{*}{2010} & \multirow{2}{*}{2015} & \multirow{2}{*}{2017} & \multicolumn{2}{|c|}{2017 у \% до } \\
\hline & & & & & & 2000 & 2015 \\
\hline \multirow{2}{*}{ Усього } & $98,3^{*}$ & 225,1 & 691,7 & 1106,0 & 1281,2 & 13,0 раза & 115,8 \\
\hline & $1278,3 * *$ & 846,5 & 698,9 & 788,8 & 817,8 & 64,0 & 103,7 \\
\hline \multirow{2}{*}{$\begin{array}{l}\text { у тому числі продукція: } \\
\text { рослинництва }\end{array}$} & 75,6 & 150,4 & 384,1 & 750,4 & 889,9 & 11,8 раза & 118,6 \\
\hline & 605,8 & 396,8 & 351,2 & 449,2 & 484,9 & 80,0 & 107,9 \\
\hline \multirow{2}{*}{ тваринництва } & 22,7 & 74,7 & 307,6 & 355,6 & 391,7 & 17,3 раза & 111,7 \\
\hline & 672,5 & 449,7 & 347,7 & 339,6 & 332,9 & 49,5 & 98,0 \\
\hline
\end{tabular}

Примітки: * чисельник - показники сільськогосподарських підприємств;

** знаменник - показники господарств населення

Так, зокрема, у 2000 р. цей відносний показник становив 1278,3 тис. грн, тимчасом як у 2017 р. він дорівнював всього 817,8 тис. грн, тобто зниження становило $36,0 \%$.

Узагальнюючи результати аналізу виробництва продукції з розрахунку на 100 га сільськогосподарських угідь господарськими формуваннями Львівщини, можна констатувати, що ці процеси будуть відбуватися і надалі. 3 цього приводу заперечень немає, адже це об'єктивний і закономірний процес розвитку аграрного виробництва в організаційно-правових формах ведення діяльності. Ми вважаємо, що цей період буде тривати доти, коли сформуються оптимальні співвідношення між великими господарськими формуваннями (сільськогосподарські підприємства) і дрібними господарськими структурами (господарствами населення).

Виробництво продукції сільського господарства як сільськогосподарськими підприємствами, так і іншими організаційно-правовими формами господарювання АПК насамперед призначається для реалізації споживачам за різними каналами збуту. Статистичні видання трактують реалізацію продукції, як “обсяги власно виробленої продукції, яка реалізована сільськогосподарськими підприємствами (крім сільськогосподарських підприємств, які не відповідають визначеним статистичною методологією критеріям) за всіма напрямами: переробним підприємствам на ринку населенню в рахунок оплати праці, пайовикам у рахунок орендної плати за землю та майнових паїв (часток), за іншими напрямами" (Korysko, 2018). Дане визначення терміну “Реалізація продукції”, що міститься у статистичних виданнях, найбільш повно i різнобічно відображає все те, що входить у це понятТя.

Отже, наведемо дані щодо кількості реалізованої продукції сільськогосподарськими підприємствами Львівщини протягом досліджуваних років у натуральних вимірах (табл. 3). Наведені дані показують, що в обсягах реалізації продукції сільського господарства сільськогосподарськими підприємствами Львівщини відбулися значні зміни протягом досліджуваного періоду, особливо відчутні ці зміни, коли порівнювати показники реалізації продукції рослинництва у 2017 р. 3 даними за 2000 р.

Таблиця 3

Реалізація продукції сільського господарства сільськогосподарськими підприємствами Львівщини, тис. т

\begin{tabular}{|c|c|c|c|c|c|c|c|}
\hline \multirow{2}{*}{ Продукція } & \multirow{2}{*}{2000} & \multirow{2}{*}{2005} & \multirow{2}{*}{2010} & \multirow{2}{*}{2015} & \multirow{2}{*}{2017} & \multicolumn{2}{|c|}{2017 у \% до } \\
\hline & & & & & & 2000 & 2015 \\
\hline Культури зернові та зернобові & 123,0 & 175,6 & 244,4 & 959,1 & 589,9 & 4,8 разу & 61,5 \\
\hline у тому числі: пшениця & 88,2 & 105,6 & 131,1 & 484,2 & 291,8 & 3,3 разу & 60,6 \\
\hline кукурудза та зерно & 0,6 & 20,7 & 68,4 & 327,7 & 127,3 & 212,2 разу & 38,8 \\
\hline ячмінь & 12,2 & 20,3 & 29,6 & 136,8 & 147,5 & 12,1 разу & 107,8 \\
\hline зернобобові & --------' & 1,5 & 0,5 & 1,9 & 18,1 & ------ & 9,5 раза \\
\hline Культури олійні & 8,4 & 7,9 & 98,7 & 213,9 & 261,7 & 31,2 разу & 122,3 \\
\hline Буряк цукровий & 136,8 & 121,3 & 459,8 & 613,9 & 756,1 & 5,5 разу & 123,2 \\
\hline Картопля & 1,7 & 1,4 & 34,1 & 40,8 & 29,0 & 17,1 разу & 71,1 \\
\hline Культури овочеві & 4,3 & 5,6 & 13,1 & 31,4 & 11,9 & 2,8 разу & 37,9 \\
\hline Культури плодові та ягідні & 0,8 & 0,5 & 0,6 & 24,6 & 11,7 & 14,6 разу & 47,6 \\
\hline $\begin{array}{l}\text { Сільськогосподарські тварини } \\
\text { (у живій масі) }\end{array}$ & 18,7 & 12,5 & 68,6 & 90,9 & 87,4 & 4,7 разу & 108,0 \\
\hline молоко & 44,2 & 23,0 & 18,9 & 21,9 & 20,9 & 47,3 разу & 95,4 \\
\hline Яйця, тис. шт & 50307 & 114229 & 133315 & 56539 & 39671 & 78,9 разу & 70,2 \\
\hline
\end{tabular}

Із порівнюваних років найкращим роком щодо реалізації продукції був 2015 р. При цьому привертають увагу обсяги реалізації продукції зернових та зернобобових культур - 959,1 тис. т, тимчасом як у 2017 р. було реалізовано значно менше - 589,1 тис. т, тобто $61,5 \%$ рівня $2015 \mathrm{p}$.

Варто також відзначити, що в останні роки інтенсивно розвиваються процеси скорочення поголів'я тварин. І це відбувається не тільки у сільськогоспо- 
дарських підприємствах, а й в інших організаційноправових структурах АПК. На подолання цих негативних явищ повинні бути спрямовані зусилля не тільки господарюючих суб'єктів аграрного виробництва, а й державних структур.

Обсяги реалізації продукції сільського господарства залежать насамперед від валового виробництва іiі суб'єктами господарювання. Щодо обсягів продукції сільського господарства, виробленої сільськогосподарськими підприємствами Львівщини, то ця інформація подана в таблиці 1. Наведені дані показують, що питома вага валової продукції, яка вироблена досліджуваними підприємствами в загальному обласному обчисленні у 2017 р. становила 38,9\%, у тому числі рослинництва 27,0\% і тваринництва 11,9\%. Ці показники вказують на те, що сільськогосподарські підприємства ще не стали пріоритетною формою господарювання, хоча рівень використання земельних угідь у них значно вищий, ніж у господарств населення (табл. 2). Однак, з іншого боку, найбільші площі земельних угідь зосереджено саме у дрібних селянських господарствах. Отож, для збільшення обсягів виробництва продукції сільського господарства сіль- ськогосподарськими підприємствами Львівщини необхідне розширення площ земельних угідь. I саме на цій основі можливе збільшення обсягів реалізації аграрної продукції досліджуваними підприємствами.

В процесі дослідження реалізації продукції сільського господарства сільськогосподарськими підприємствами, поряд із іншими чинниками, відіграють ціни реалізації, які в статистичних виданнях трактуються: “як середня вартість одиниці (тонни, тисячі штук) реалізованої продукції з урахуванням ії̈ якості, але без урахування податку на додану вартість, дотації, накладних транспортних та експедиційних витрат, яка розраховується шляхом ділення вартості реалізованої за відповідний період продукції на іiі кількість. У 2000-2011 роках до середньої ціни відносилися суми дотацій за рахунок коштів податку на додану вартість та бюджетні дотації, з 2012 року - не включаються" (Korysko, 2017). Ось таким є порядок формування середніх цін реалізації аграрної продукції в державі. Середній рівень цін реалізації продукції сільського господарства у підприємствах Львівщини показані в таблиці 4.

\section{Таблиця 4}

Середні ціни реалізації продукції сільського господарства сільськогосподарськими підприємствами Львівщини, грн за $1 \mathrm{~T}$

\begin{tabular}{|c|c|c|c|c|c|c|c|}
\hline \multirow{2}{*}{ Продукція } & \multirow{2}{*}{$2000^{*}$} & \multirow{2}{*}{$2005^{*}$} & \multirow{2}{*}{2010} & \multirow{2}{*}{2015} & \multirow{2}{*}{2017} & \multicolumn{2}{|c|}{2017 у \% до } \\
\hline & & & & & & 2000 & 2015 \\
\hline Культури зернові та зернобові & 577,8 & 559,3 & 1256,8 & 2559,6 & 3800,1 & 6,6 & 128,4 \\
\hline у тому числі: пшениця & 595,5 & 512,3 & 1247,1 & 3047,8 & 3753,1 & 6,3 & 123,1 \\
\hline кукурудза та зерно & 419,0 & 1004,6 & 1260,6 & 2744,7 & 3620,1 & 8,6 & 131,9 \\
\hline ячмінь & 520,4 & 487,6 & 1119,4 & 3085,3 & 2756,1 & 5,3 & 89,3 \\
\hline зернобобові & --------- & 457,8 & 1937,4 & 4606,6 & 5902,9 & ----- & 128,1 \\
\hline Культури олійні & 536,5 & 567,3 & 4746,6 & 7438,6 & 9621,6 & 17,9 & 129,3 \\
\hline Буряк цукровий & 119,6 & 183,8 & 483,3 & 890,6 & 790,5 & 6,6 & 88,8 \\
\hline Картопля & 426,3 & 737,8 & 2450 & 2351,0 & 3478,6 & 8,2 & 148,0 \\
\hline Культури овочеві & 1227,5 & 2839,9 & 4794,2 & 4889,9 & 9429,3 & 7,7 & 192,8 \\
\hline Культури плодові та ягідні & 370,1 & 649,4 & 6415,0 & 8264,3 & 7850,6 & 21,2 & 94,8 \\
\hline $\begin{array}{l}\text { Сільськогосподарські тварини } \\
\text { (у живій масі) }\end{array}$ & 2123,2 & 6370,8 & 9564,1 & 18437,2 & 27253,8 & 12,8 & 147,8 \\
\hline молоко & 503,1 & 1067,3 & 2722,4 & 4330,4 & 6805,2 & 13,5 & 157,1 \\
\hline Яйця, тис. шт & 208,6 & 252,7 & 454,3 & 1069,2 & 1097,4 & 5,3 & 102,6 \\
\hline
\end{tabular}

Примітка: * дані за 2000 і 2005 рр. використані зі статистичного збірника за 2016 р. (Zymovina, 2018).

Наведені дані показують, що ціни реалізації продукції, яка вироблена сільськогосподарськими підприємствами, не є стабільними протягом досліджуваного періоду. Так, скажімо, коли порівняти ціни 2017 p. 3 цінами 2000 р., то вони зросли за 17 років в декілька разів, а інколи в десятки разів. 3 іншого боку, коли порівняти ціни реалізації 2017 р. $з 2015$ р., то їх зміни характеризуються значно меншими величинами, ніж у порівнянні з 2000 р. До того ж ці зміни відбуваються як у бік збільшення, так і зменшення щоб пояснити, чому це відбувається саме так, а не інакше, потрібендеталізований аналіз функціонування цінового механізму, а це окрема тема наукового дослідження.

\section{Висновки}

Проведення дослідження за обраною темою дає можливість прослідкувати, як відбуваються процеси виробництва продукції сільського господарства та іiі реалізація сільськогосподарськими підприємствами Львівщини. Одержані результати дослідження дають підстави констатувати:

- за досліджуваний період (2000-2017 рр.) відбулись значні зміни збільшення виробництва продукції сільського господарства у 2017 р. порівняно з 2000 р. у декілька разів, а при порівнянні з 2015 р. - в межах 119,1-128,3\%. Відбулись позитивні зміни щодо використання земельних угідь;

- значно зросли обсяги реалізації продукції, що вироблена сільськогосподарськими підприємствами. Зокрема, продаж продукції рослинництва у 2017 р. 
порівняно з 2015 р. зріс у декілька, а в окремих випадках - декілька десятків і більше разів. Проте продукція тваринництва (молоко і яйця), іiї обсяги реалізації не досягли рівня 2000 р. Потрібне деталізоване вивчення цінового механізму реалізації продукції.

Отже, одержані результати дослідження виробництва і реалізації продукції сільського господарства сільськогосподарськими підприємствами Львівщини вказують на те, що суб'єкти господарювання хоча i досягли певних зрушень, однак вони ще не стали визначними у веденні аграрного виробництва. Тому в сьогоднішніх умовах слід розробляти і впроваджувати конкретні заходи щодо підвищення їх вагомості у сільськогосподарському виробництві.

Перспективи подальших досліджень. Подальший розвиток аграрного виробництва як на державному, так і на регіональному рівнях вимагає конкретного вивчення пріоритетних форм господарювання. На наше переконання, це мають бути сільськогосподарські підприємства, які можуть забезпечити впровадження передових технологій виробництва і реалізації продукції, прогресивних форм організації і оплати праці тощо. Одночасно зауважимо, що в сучасних умовах i на перспективу слід надавати допомогу i підтримку малим формам господарювання. Необхідно домогтися оптимального поєднання їх інтересів та можливостей у веденні аграрного виробництва.

\section{References}

Andriichuk, V.H. (2005). Efektyvnist diialnosti ahrarnykh pidpryiemstv: teoriia, metody, analiz: Monohrafiia. K.: KNEU (in Ukrainian).

Hadzalo, Ya.M., Vashchenko, T.U., Zhuk, V.M., \& Lupenko, Yu.O. (2016). Stratehiia rozvytku silskohospodarskoho vyrobnytstva $\mathrm{v}$ Ukraini na period do 2025 roku. K.: Ahrarna nauka (in Ukrainian).

Korysko, H. (2017). Silsike gospodarstvo. Statystychnyj zbirnyk. Lviv (in Ukrainian).

Korysko, H. (2018). Silske hospodarstvo Lvivskoi oblasti. Statystychnyi zbirnyk. Lviv (in Ukrainian).

Mesel-Veseliak, V.Ya. (2012). Formy hospodariuvannia v silskomu hospodarstvi Ukrainy (rezultaty, problemy vyrishennia). Ekonomika APK, 1, 13-23 (in Ukrainian).

Shulskyj, M.H. (2016). Efektyvnist dijalnosti silskogospodarskyh pidpryjemstv Lvivshhyny. Naukovyj visnyk Lvivskogo nacionalnogo universytetu veterynarnoi medycyny ta biotehnologij imeni S.Z. Hzhyc'kogo. Serija: Ekonomichni nauky, 18, 2(69), 188192. doi: 10.15421/nvlvet6935 (in Ukrainian).

Smolynec, I.B. (2017). Analiz rozvytku riznyh organizacijno-pravovyh form pidpryjemnyckoi dijalnosti v agrarnomu sektori. Naukovyj visnyk Lvivskogo nacionalnogo universytetu veterynarnoi medycyny ta biotehnologij imeni S.Z. Hzhyckogo. Serija: Ekonomichni nauky, 19(76), 100-107. doi: 10.15421/nvlvet7620 (in Ukrainian).

Zymovina, S. (2018). Statystychnyj shhorichnyk Lvivskoi oblasti za 2017 rik. Chastyna 1. Lviv (in Ukrainian). 